\title{
Effects of Additional Radial Shockwave Therapy to Median Nerve Gliding Exercises on Hand Grip Strength in Carpal Tunnel Syndrome Patients
}

\section{Cornelia Arina Pradipta', Rudy Handoyo ${ }^{1}$, Hari Peni Julianti ${ }^{1}$, Hindun Zuhdiana ${ }^{1}$, Noviolita Dwi Kusumawati ${ }^{1}$}

${ }^{1}$ Department of Physical Medicine and Rehabilitation, Diponegoro University, Semarang, Indonesia

\begin{abstract}
Introduction: Carpal Tunnel Syndrome (CTS) is one of the most common entrapment neuropathies found in the upper extremities. Patients with moderate and severe CTS usually experience disturbances in motor strength. A non-invasive therapeutic method that has recently emerged in the treatment of CTS is Radial Shock Wave Therapy (RSWT). RSWT is a therapy using shock waves and can be added to other forms of exercise. The addition of RSWT in CTS is expected to increase the grip strength. Research that directly assesses the effect of adding RSWT and median nerve gliding exercises on hand grip strength in CTS patients has not been conducted.

Methods: This study was a pre-test/post-test control group design. There were 22 moderate grade CTS subjects divided into 2 groups, the control group was received median nerve gliding exercise $(n=11)$ and the treatment group was received additional RSWT on median nerve gliding exercise $(\mathrm{n}=11)$. Assessment of grip strength by Jamar hand dynamometer was performed before and after 4 weeks of treatment. The mean differences before and after treatment, as well as between groups was compared statistically using an unpaired t-test.
\end{abstract}

Results: There was no significant difference in the handgrip strength of the control group $(p=0.094)$, and a significant difference in the treatment group $(\mathrm{p}=0.009)$ before and after the intervention. However, there were no significant differences in grip strength between the two groups $(\mathrm{p}=0.065)$.

Conclusion: There was no significant effect of adding RSWT on improving handgrip strength in CTS patients who received a median nerve gliding exercise.

Keywords: carpal tunnel syndrome, entrapment neuropathies, grip strength, nerve gliding exercise, radial shockwave therapy 


\section{ABSTRAK}

Pendahuluan: Carpal Tunnel Syndrome (CTS) merupakan salah satu neuropati akibat jebakan yang paling umum dijumpai pada ekstremitas atas. Penderita CTS sedang dan berat biasanya mengalami gangguan pada kekuatan motorik. Metode terapi non-invasif yang baru muncul dalam pengobatan CTS adalah Radial Shock Wave Therapy (RSWT). RSWT yaitu terapi menggunakan gelombang kejut dan dapat ditambahkan pada bentuk latihan lain. Penambahan RSWT pada pasien penderita CTS diharapkan dapat meningkatkan perbaikan kekuatan menggenggam. Penelitian yang secara langsung menilai pengaruh penambahan RSWT dan latihan gliding nervus medianus terhadap kekuatan menggenggam tangan penderita CTS sampai saat ini belum dilakukan

Metode: Penelitian ini merupakan randomized controlled trial. Terdapat 22 subjek pasien CTS derajat sedang dibagi menjadi 2 kelompok, yaitu kelompok kontrol yang mendapat latihan gliding nervus medianus (11 orang) dan kelompok perlakuan yang mendapat penambahan RSWT pada latihan gliding nervus medianus (11 orang). Penilaian kekuatan menggenggam dengan dynamometer Jamar diukur sebelum dan sesudah 4 minggu perlakuan. Perbedaan rerata antar kelompok diukur secara statistik dengan menggunakan uji T tidak berpasangan.

Hasil: Tidak terdapat perbedaan bermakna pada kekuatan genggaman tangan kelompok kontrol $(\mathrm{p}=0.094)$, dan terdapat perbedaan bermakna pada kekuatan genggaman tangan kelompok perlakuan $(\mathrm{p}=0.009)$ setelah diberikan intervensi. Tidak terdapat perbedaan bermakna rerata kenaikan kekuatan menggenggam diantara kedua kelompok $(\mathrm{p}=0.065)$.

Kesimpulan: Tidak terdapat efek penambahan RSWT terhadap peningkatan kekuatan genggaman otot tangan penderita CTS yang mendapatkan latihan gliding nervus medianus.

Kata Kunci: carpal tunnel syndrome, entrapment neuropathies, kekuatan menggenggam, nerve gliding exercise, radial shockwave therapy

\section{Correspondent Detail:}

\section{Cornelia Arina Pradipta}

Email: arina09.med@gmail.com

Department of Physical Medicine and

Rehabilitation, Faculty of Medicine

Diponegoro University, Kariadi General

Hospital, Semarang, Indonesia

\section{INTRODUCTION}

Carpal Tunnel Syndrome (CTS) is one of the most common entrapment neuropathies in the upper extremities and is caused by increased pressure in carpal tunnel. ${ }^{1}$ Conservative treatment is the first choice alternative for mild and moderate CTS. One of the conservative therapies that has proven effective in patients with CTS is exercise therapy. ${ }^{2}$ However, nerve gliding exercises require a combination with other conservative therapies to obtain optimal results..$^{2-4}$

An emerging non-invasive therapeutic method in the treatment of CTS is Extracorporeal Shock Wave Therapy (ESWT). ESWT is an acoustic wave with high peak pressure (100MPa), short duration $(10 \mu \mathrm{s})$, energy density between $0.003-0.89 \mathrm{~mJ} /$ $\mathrm{mm}^{2}$. The effect of ESWT is to reduce pain from 
peripheral nerve damage, increase remodeling and regeneration of local arteries. ESWT is classified into focused ESWT (ESWT) and radial ESWT (RSWT). RSWT has a characteristic wave that spreads eccentrically from the tip of the applicator without focusing energy on the targeted place so that the focus of energy on target point is less due to the lower depth of wave penetration when compared to fSWT $(3 \mathrm{~cm}: 12 \mathrm{~cm}){ }^{5-7}$

Patients with moderate and severe CTS usually have impaired motor strength. Grip strength is a relevant functional variable for assessing functional health status in patients with CTS and is considered a predictor of return to work. Grip strength has been shown to be associated with quality of life in CTS patients. ${ }^{8}$

The purpose of this study was to determine the effect of adding RSWT to the median nerve gliding exercise on hand grip strength of patients with CTS. Research that directly assesses the effect of adding RSWT and median nerve gliding exercises on hand grip strength in CTS sufferers has not yet been conducted.

\section{METHODS}

This study was a randomized controlled trial. It was carried out at the outpatient Medical Rehabilitation Polyclinic of KRMT Wongsonegoro General Hospital Semarang, conducted from March 18 until April 19, 2021. Control group was received median nerve gliding exercise $(n=11)$ and treatment group was received additional RSWT on median nerve gliding exercise $(n=11)$. Assessment of grip strength by Jamar hand dynamometer was performed before and after 4 weeks of treatment.
Inclusion criteria including patients who met the diagnostic criteria for CTS (subjects with pain in fingers 1-3 and half of $4^{\text {th }}$ finger according to the distribution of median nerve for more than 4 weeks on one hand, motor examination did not reveal atrophy of the muscles innervated by median nerve distal to the carpal tunnel such as abductor pollicis brevis, opponent pollicis, flexor pollicis brevis, first and second lumbrical muscles, with positive median nerve provocative examination), moderate CTS based on Electromyography (EMG) examination, patients aged 30-50 years, and patients with VAS 3-5.

Exclusion criteria were patients who have secondary etiology of CTS, such as diabetes mellitus, hypothyroidism, hand infection, congenital carpal tunnel deformity, wrist tumor, hand edema, pregnancy, drug use (oral contraceptives, anticoagulants), neuromusculoskeletal disorders (eg hand fracture, anticoagulant, thopus gout, rheumatoid arthritis, parkinsonism, stroke paresis, SCI, drop hand, hand amputation, hand joint contracture, ulnar neuropathy, leprosy), patients were undergoing exercise to increase grip strength, fine motor, occupational therapy for fine motor or function hands regularly $3-5 x /$ week, patients undergoes special activities that use they hand regularly $>3 \mathrm{x} /$ week such as playing piano, embroidering, knitting, sewing, cooking for a living, kneading dough, patient has undergone CTS decompression surgery, received conservative therapy another for complaints of CTS, there were contraindications to median nerve gliding.

Drop out criteria were patients who absent 1 time in RSWT therapy, unwanted side effects occurred in form of a large hematoma in treated 
area, the number of median nerve gliding exercises was less than $80 \%$ (no median nerve gliding exercise 16 times for 4 weeks) and did not perform nerve gliding exercises for 3 consecutive days, received other conservative therapy while the study was running, and did not comply with study procedures.

Treatment group was received additional RSWT in the area between tendons of flexor carpi radialis and palmaris longus muscles as much as 4 sessions ( 1 session per week) in the Rehabilitation Polyclinic of KRMT Wongsonegoro General Hospital Semarang and median nerve gliding exercises 84 times for 4 weeks with a frequency of 3 times daily for 4 weeks independently at home. Control group only received median nerve gliding exercise as much as 84 times for 4 weeks with a frequency of 3 times every day independently.

Data were collected from data collection sheet then coded, tabulated and inputed into computer. When testing the normality of data distribution using the Shapiro-Wilk test, it obtained were normally distributed (BMI, GDS). Data that were not normally distributed were age, VAS. Nominal data, namely gender, occupation, affected side, repetitive movements were tested using chi square hypothesis. Data that were normally distributed were tested using an unpaired t-test, while those that were not normally distributed were used the MannWhitney $U$ test. The difference before and after treatment for each group used a paired t-test because it were normally distributed. All of data were computerized and processed using SPSS ${ }^{\circledR}$ software. Significance in this study was obtained if the $\mathrm{p}$ value $<0.05$ with $95 \%$ confidence intervals.
Before conducting the research, this study has been passed the ethical clearance test by Ethical Commission of the Faculty of Medicine, Diponegoro University/Dr. Kariadi General Hospital Semarang 762/EC/KEPKRSDK/2021 and from KRMT Wongsonegoro Hospital Semarang B/1452/070/III/2021.
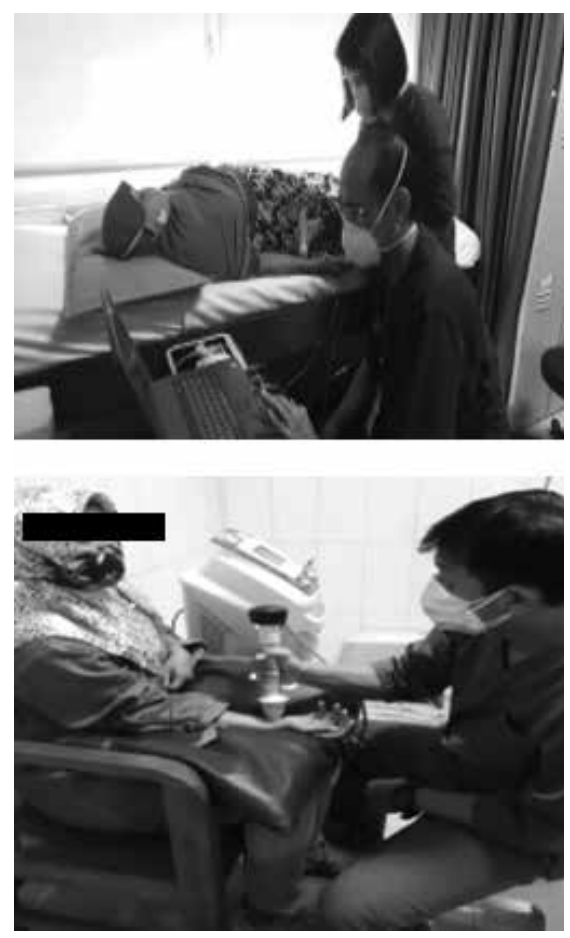

Figure 1. Patients during EMG and RSWT

\section{RESULTS}

Until the end of the study, total data analyzed were 22 people. There were 2 subjects who dropped out in this study for the following reasons: 1 subject did not come more than 1 on RSWT schedule and 1 subject was received surgery. One subject was excluded based on initial outlier screening.

There were three subjects who complained of pain during RSWT procedure, but after intervention there were no complaints of pain so they did not require additional analgesic drugs. There were no side effects or other 
complications after RSWT such as redness, hematoma in treatment group during the study period.

The characteristics of data can be seen in Table 1. There was no significant differences between both groups. Research subjects are in productive age range. Demographic characteristics include age, gender, occupation, affected side, repetitive movement habits, BMI, and VAS in both homogeneous groups.

At the beginning of study, the mean initial grip strength before intervention in intervention group was $29.43 \pm 4.96$ and in control group was $37.76 \pm 12.41$ with $p$ value $=0.060$. Grip strength was reassessed in both groups after 4 weeks. Mean grip strength score in intervention group was $37.83 \pm 9.57$ and in control group was $40.55 \pm 12.53$ with $p$ value $=0.587$.

It can be seen in Table 2 that there is a significant difference in mean grip strength before and after treatment in intervention group $(\mathrm{p}=0.009)$ and there is no significant difference in control group $(\mathrm{p}=0.094)$.

The mean improvement (delta) of grip strength scores in intervention group was $8.40 \pm 7.96$ and in control group $2.79 \pm 5.00$. Statistically there was no significant mean improvement grip strength scores in both groups $(\mathrm{p}=0.065)$.

Table 1. Characteristics of the participants $(n=22)$

\begin{tabular}{lccc}
\hline \multirow{2}{*}{ Variable } & \multicolumn{2}{c}{ Group } & p \\
\cline { 2 - 3 } & Intervention & Control & $0.164 \ddagger$ \\
Age & $44.55 \pm 6.41$ & $43.27 \pm 3.23$ & $0.238 ¥$ \\
Male & & & \\
Female & $0(0 \%)$ & $2(18.2 \%)$ & \\
Occupation & $11(100 \%)$ & $9(81.8 \%)$ & $0.231 ¥$ \\
Housewife & & & \\
Cleaning & $3(27.3 \%)$ & $1(9.1 \%)$ & \\
Service & $3(27.3 \%)$ & $8(72.7 \%)$ & \\
Chef & $2(18.2 \%)$ & $1(9.1 \%)$ & \\
Administration & $1(9.1 \%)$ & $1(9.1 \%)$ & \\
Dentist Nurse & $2(18.2 \%)$ & $0(0 \%)$ & \\
Affected side & & & \\
Right & $7(63.6 \%)$ & $7(63.6 \%)$ & $1.000 ¥$ \\
Left & $4(36.4 \%)$ & $4(36.4 \%)$ & \\
Repetition movement & $11(100 \%)$ & $10(90.9 \%)$ & $0.112 \S$ \\
Yes & $0(0 \%)$ & $1(9.1 \%)$ & $0.537 \ddagger$ \\
No & $27.14 \pm 2.66$ & $24.92 \pm 3.53$ & \\
IMT & $4.45 \pm 0.93$ & $4.27 \pm 0.91$ & \\
VAS & & & \\
\hline
\end{tabular}

* Significant; $§$ Independent $t$; $\$$ Mann whitney; $¥$ Chi square 
Table 2. Comparison of mean Jamar value between intervention and control group

\begin{tabular}{cccc}
\hline Jamar & \multicolumn{2}{c}{ Group } & p \\
\cline { 2 - 4 } & Intervention & Control & $0.060 \S$ \\
\hline Pre test & $29.43 \pm 4.96$ & $37.76 \pm 12.41$ & $0.587 \S$ \\
Post test & $37.83 \pm 9.57$ & $40.55 \pm 12.53$ & \\
\hline $\mathrm{p}$ & $0.009 \boldsymbol{q}^{*}$ & $0.094 \boldsymbol{9}$ & $0.065 \S$ \\
\hline Delta & $8.40 \pm 7.96$ & $2.79 \pm 5.00$ &
\end{tabular}

* Significant; $\S$ Independent t; + Mann Whitney; 9 Paired t; † Wilcoxon

\section{DISCUSSION}

There were no statistically significant differences in participants characteristics including age, sex, BMI, affected side, type of occupation, and VAS (Table 1) between both groups ( $\mathrm{p}$ value $>0.05$ ). The conclusion from the data in Table 1 is that characteristics of the research subjects in both groups are homogeneous.

The measurement of grip strength in this study used a Jamar hand dynamometer with units of kilogram force. It took dominant hand where in this study the dominance of hand of all research subjects was right hand.

In comparison of the results pre-test and posttest, only intervention groups had a significantly increased mean score for grip strength futhermore the post-test results in intervention group had a significantly better improvement than those of the control group.

Patients with CTS, the motor function of the intrinsic muscles of the hand, especially the abductor pollicis brevis, is important because main intervention of this muscle gets from the motor branch of the median nerve after exiting the carpal tunnel. The presence of axonal degeneration in motor branch of median nerve will affect muscle strength.

RSWT stimulates endothelial nitric oxide production, angiogenesis, and neurogenesis through the involvement of vascular endothelial growth factor. This provides an indirect effect of RSWT, which reducing the degree of tissue inflammation through its role in the formation of new blood vessels. The formation of new blood vessels can accelerate tissue healing (remodeling process) so that edema and inflammation are reduced more quickly. It occurs in 4 weeks. ${ }^{9,10}$

The effect of angiogenesis on RSWT intervention is directly proportional to process of neurogenesis. Increased distal axonal regeneration began to be seen at beginning of the $3^{\text {rd }}$ week in damaged nerves using electron microscopy. Functional improvement began to be seen in denervated muscles at week 4. However, the reinnervation process of median nerve will continue until the $10^{\text {th }}$ week. ${ }^{11}$ This result was in accordance with a study held by Raissi et al. ${ }^{12}$ that reported that the existence of a neurogenesis process in median nerve based on EMG examination after RSWT intervention, have improvements in distal latency Sensory Nerve Action Potential (SNAP) and distal latency Compound Muscle Action Potential 
(CMAP) at week 3 after RSWT in patients with moderate CTS, and Chang et al. ${ }^{13}$ that reported that changes in the distal median nerve motor latency after RSWT.

Control group who only received median nerve gliding exercise there was an increase in grip strength before and after intervention but there was no statistically significant difference. A previous study described improvements in hand grip strength at week 4 after 3 weeks of median nerve gliding exercise. ${ }^{14}$ Nerve gliding exercise is one of the conservative therapies that has been proven to be effective in patients with CTS. Median nerve gliding exercise has a biomechanical impact that can improve neural mobilization by stretching the adhesion between tendon and median nerve, reducing tenosynovial edema, being able to improve venous return pressure so can reduce pressure in carpal tunnel.

Meanwhile, when an analysis of the value of change (delta) was performed, it appeared that mean improve in grip strength scores was greater in the intervention group than control group, but statistically not significant. In this study, measurements were made at week $4^{\text {th }}$ after the intervention, while in literature the maximum improvement was seen at week $10^{\text {th }}$ and could last up to week $12^{\text {th }}$ after RSWT intervention. Measurements in a short period of time make the measurement results obtained are not optimal. In addition, the effect of RSWT therapy and median nerve gliding exercise did not have a direct effect on muscles so that it had little effect on the measurement results. Both of these interventions only focus on the regeneration of median nerve which have an effect on repairing the denervated muscle. ${ }^{11,15}$

\section{LIMITATION OF STUDY}

In this study, repetitive hand activity was still carried out by several subjects that this condition could affect the clinical condition of CTS. In addition, evaluation during the intervention was only carried out once, at the end of $4^{\text {th }}$ week from intervention so that it could not assess the effect of RSWT on improving hand grip strength every week.

\section{CONCLUSION}

There was no significant effect of adding RSWT on improving handgrip strength in CTS patients who received a median nerve gliding exercise.

\section{REFERENCES}

1. Wipperman J, Goerl K. Diagnosis and management of carpal tunnel syndrome. J Musculoskelet Med 2016; 94: 47-60.

2. Martins RS, Siqueira MG. Manejo terapêutico conservador da síndrome do túnel do carpo. Arq Neuropsiquiatr 2017; 75(11): 819-24.

3. Kim SD. Efficacy of tendon and nerve gliding exercises for carpal tunnel syndrome: A systematic review of randomized controlled trials. J Phys Ther Sci 2015; 27(8): 2645-8.

4. Ballestero-Pérez R, Plaza-Manzano G, Urraca-Gesto A, Romo-Romo F, AtínArratibel M de los Á, Pecos-Martín D, et al. Effectiveness of nerve gliding exercises on carpal tunnel syndrome: a systematic review. J Manipulative Physiol Ther 2016; 
40(1): 1-10.

5. Wu Y, Ke M, Chou Y, Chang C, Lin C, Li T, et al. Effect of radial shock wave therapy for carpal tunnel syndrome. J Orthop Res 2016; 34(6)(June): 977-84.

6. Rashad UM, Kishk NA, Mansour WT, Nawito AM, Khalil AS, Helmy H, et al. Effect of extracorporeal shock wave therapy on different severities of carpal tunnel syndrome. Egypt J Neurol Psychiatry Neurosurg 2020; 56(1).

7. Ke M, Chen L, Chou Y, Li T, Chu H. The dose-dependent efficiency of radial shock wave therapy for patients with carpal tunnel syndrome : a prospective. Nat Publ Gr 2016; 161: 2-11.

8. Núñez-Cortés R, Cruz-Montecinos $\mathrm{C}$, Antúnez-Riveros MA, Pérez-Alenda S. Does the educational level of women influence hand grip and pinch strength in carpal tunnel syndrome? Med Hypotheses 2020; 135(August 2019): 109474.

9. Shockwave Theory [Internet]. Available from: https://www.shockwavetherapy. education/index.php/theory/types-ofshockwave.

10. Ito $\mathrm{K}$, Fukumoto $\mathrm{Y}$, Shimokawa $\mathrm{H}$. Extracorporeal shock wave therapy as a new and non-invasive angiogenic strategy. Tohoku J Exp Med 2009; 219: 1-9.

11. Hausner T, Nógrádi A. The use of shock waves in peripheral nerve regeneration: new perspectives? Int Rev Neurobiol 2013; 109: 85-98.

12. Raissi GR, Ghazaei F, Forogh B. The effectiveness of radial extracorporeal shock waves for treatment of carpal tunnel syndrome : a randomized clinical. Ultrasound Med Biol 2016; 43(2): 1-8.

13. Chang CY, Chen LC, Chou YC, Li TY, Ho TY, Wu YT. The effectiveness of plateletrich plasma and radial extracorporeal shock wave compared with platelet-rich plasma in the treatment of moderate carpal tunnel syndrome. Pain Med 2020; 21(8): 1668-75.

14. Baysal O, Altay Z, Ozcan C, Ertem $\mathrm{K}$, Yologlu S. Comparison of three conservative treatment protocols in carpal tunnel syndrome. Int J Clin Pract 2006; 60(July): 820-8.

15. Unver S, Akyolcu N. The effect of hand exercise on reducing the symptoms in hemodialysis patients with carpal tunnel syndrome. Asian J Neurosurg 2018; 1(13): 31-6. 